\title{
Evaluation of Pseudomonas aeruginosa ATCC 27853 for Bio-hydrogen production from El-Salam Canal Water. Aida H. Afify ${ }^{1}$; A. M. Abd EL Gwad ${ }^{2}$ and N. K. Abd EL Rahman ${ }^{2}$ \\ ${ }^{1}$ Microbiology Dept., Fac. Agric., Mansoura Univ., Mansoura, Egypt. \\ ${ }^{2}$ Soil Fertility and Microbiology Dept., Desert Res. Center, Matariya, Cairo, Egypt.
}

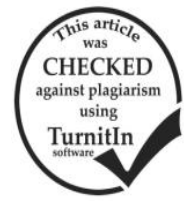

\section{ABSTRACT}

In this study EL-Salam canal water was used as substrate for Bio-hydrogen production in microbial electrolysis (MECs) by Pseudomonas aeruginosa ATCC 27853 and without addition of bacteria. The highest hydrogen yield was $31.18 \%$ and the highest volume of Bio- $\mathrm{H}_{2}$ production was $51.1 \mathrm{~cm}^{3}$ from Salam canal water at the anode chamber $500 \mathrm{ml}$ with power supply 0.8 V without addition of Pseudomonas aeruginosa ATCC 27853. While the highest hydrogen yield was $75.29 \%$ and the highest volume of Bio- $\mathrm{H}_{2}$ was $148.25 \mathrm{~cm}^{3}$ production by Pseudomonas aeruginosa ATCC 27853 from EL-Salam canal water at the anode chamber $500 \mathrm{ml}$ with power supply $0.4 \mathrm{~V}$.

Keywords: EL-Salam canal water, Microbial electrolysis cells, Bio-hydrogen, Pseudomonas aeruginosa ATCC 27853.

\section{INTRODUCTION}

Bacteria and cyanobacteria was used as biological process for Bio-hydrogen $\left(\mathrm{Bio}-\mathrm{H}_{2}\right)$ production from biomass, wastewater and waste materials, biological process included fermentation methods, bio-photolysis and microbial electrolysis ( MECs ). (Kotay and Das, 2008)

MECs are a new technology for bio-hydrogen $\left(\right.$ Bio- $\left.\mathrm{H}_{2}\right)$ produced from organic matter. In MEC, at the positive (anode) chamber protons, electrons and $\mathrm{CO}_{2}$ electrochemically active bacteria oxidize organic matter in wastewater. Electrons were transferred by bacteria from positive (anode) electrode to negative (cathode) electrode through a wire which connection between two electrodes. Protons were transferred to production chamber (negative chamber) through membrane or salt bridge. Hydrogen $\left(\mathrm{Bio}-\mathrm{H}_{2}\right)$ produced in $\mathrm{MEC}$ at the negative (cathode) chamber when free protons were combined with electrons. MEC as bioreactor for biohydrogen production was needed power supply at lest $0.4 \mathrm{~V}$ to complete production of Bio-hydrogen. (Liu et al., 2005).

This study aims to El-Salam canal water was used as substrate in MEC as bioreactor for bio-hydrogen production and Hydrogen yield (\%) with and without addition of Pseudomonas aeruginosa ATCC 27853. Studies the effect of volume of anode chamber $(300,400$ and $500 \mathrm{ml}$ ) with power supply $(0.4 \mathrm{~V}, 0.6 \mathrm{~V}$ and $0.8 \mathrm{~V})$.

\section{MATERIALS AND METHODS}

Preparation of Bacteria and Substrate:

Pseudomonas aeruginosa ATCC 27853 was used as bacteria for Bio-hydrogen. It was obtained from microbiological resource center (Cairo MIRCEN), Fac. of Agric., Ain Shams Univ., Cairo, Egypt. Nutrient broth medium (13gm / liter of distilled water) was used for preparation of bacterial culture (Afify, et al. 2017 a ).

EL-Salam canal water was used as substrate for Bio-hydrogen. It was obtained from water-lifting No.5 Baloza zone, North Sinai, Egypt. Drops of (1M) HCl acid was added to EL-Salam canal water the substrate for adjusted $\mathrm{pH}$ to 7 and $0.2 \mathrm{M}$ sodium phosphate buffer solution(Abd El- Rahman , 2017 ).

\section{Microbial electrolysis cells (MECs):}

MEC was used as Bio-electrochemical reactor for Bio-hydrogen production. It consists of anode and cathode chambers separated by salt bridge (agar $20 \%+$ $1 \mathrm{M}$ of Potassium Chloride) as membrane. Volume of each chamber has a 300, 400 and $500 \mathrm{ml}$. Carbon brush (No.34 D) plate as anode electrode and stainless steel (304) as cathode electrode were connected to power supply. Anode chamber was filled with domestic wastewater (300, 400 and $500 \mathrm{ml})$ and 30,40 and $50 \mathrm{ml}$ $(10 \% \mathrm{v} / \mathrm{v})$ of bacterial culture. Cathode chamber was filed by 300,400 and $500 \mathrm{ml}$ of distilled water. Copper wire connected between positive and negative electrodes of power supply $(0.4 \mathrm{~V}, 0.6 \mathrm{~V}$ and $0.8 \mathrm{~V} /$ 500 mA / DC / 50 Hz)Abd El- Rahman, 2017.

Volume of Bio-hydrogen $\left(\mathrm{Bio}-\mathrm{H}_{2} \mathrm{~cm}^{3}\right)$ :

Bio-hydrogen produced in cathode chamber was collected in burettes tubes by downward displacement of water Ujwal et al., (2015).

Volume of $\mathrm{Bio}-\mathrm{H}_{2}\left(\mathrm{~cm}^{3}\right)=$ length of burette reading $(\mathrm{cm}) \times \pi \mathrm{r}^{2}\left(\mathrm{~cm}^{2}\right)$

Where: $\pi=3.14, \quad r=$ radius of burette tube

Hydrogen yield ( $\left.\mathrm{YH}_{2} \%\right)$ :

Hydrogen Yield $\left(\mathrm{YH}_{2}\right)$ is the amount of hydrogen production from a substrate. It is calculated as: (Logan et al., 2008)

$$
\mathrm{YH}_{2}=\left({ }^{\mathrm{n}} \mathrm{H}_{2} /{ }^{\mathrm{n}} \text { th }\right) \times 100 \%
$$

Where: ${ }^{n} \mathrm{H}_{2}$ is the moles of hydrogen were produced in the experiments is calculated as:

$$
{ }^{\mathrm{n}} \mathrm{H}_{2}=\mathrm{VH}_{2} / \mathrm{R} \mathrm{T}
$$

$\mathrm{VH}_{2}$ is volume of Bio- $\mathrm{H}_{2},(\mathrm{R})$ is gas constant ( $0.08314 \mathrm{~L}$ bar $/ \mathrm{K} \mathrm{mol}$ ) and $(\mathrm{T})$ is the absolute temperature $(303 \mathrm{~K})$

${ }^{n}$ th is the moles of substrate converted. The hydrogen yield was based on COD is calculated each mole of COD removed could produce $2 \mathrm{~mol}$ of hydrogen. ${ }^{\mathrm{n}}$ th was calculated as:

$$
{ }^{\mathrm{n}} \mathrm{th}=2 \Delta \mathrm{COD} / \mathrm{MO}_{2}
$$

$$
\Delta \mathrm{COD}=\mathrm{COD}_{\mathrm{i}}-\mathrm{COD}_{\mathrm{e}}
$$

Where: $\mathrm{M} \mathrm{O}_{2}(32 \mathrm{gm} / \mathrm{mol})$ is the molecular weight of oxygen, $\left(\mathrm{COD}_{\mathrm{i}}\right)$ is the COD concentration of the substrate at the beginning and (COD $\left.{ }_{e}\right)$ is the COD concentration of the substrate at the end.

Statistical analysis:

Statistical analysis of data was carried out according to (Statistix 9) for Windows using LSD test to compare between means values. 


\section{RESULTS AND DISCUSSION}

Hydrogen yield (\%) and Bio-hydrogen produced from EL-Salam canal water without bacteria:

EL-Salam canal water was used at the substrate in MECs for Bio-hydrogen production. It filled in anode chamber $(300,400$ and $500 \mathrm{ml})$ and distilled water in cathode chamber $(300,400$ and $500 \mathrm{ml})$ respectively. Hydrogen gas was produced in cathode chamber started from sixth day at anode chamber $500 \mathrm{ml}$ with power supply $0.6 \mathrm{~V}$ and $0.8 \mathrm{~V}$ to tenth day at the anode chamber $300 \mathrm{ml}$ with power supply $0.4 \mathrm{~V}$ and $0.6 \mathrm{~V}$. The highest volume of Bio- $\mathrm{H}_{2} 51.1 \mathrm{~cm}^{3}$ production at the anode chamber $500 \mathrm{ml}$ with power supply $0.8 \mathrm{~V}$. The lowest volume of Bio- $\mathrm{H}_{2} 19.73 \mathrm{~cm}^{3}$ production at the anode chamber $300 \mathrm{ml}$ with power supply $0.4 \mathrm{~V}$, which referring significant differences were found between other volumes of $\mathrm{Bio}-\mathrm{H}_{2}$ and this volume. No significant differences were found between all the volumes of $\mathrm{Bio}-\mathrm{H}_{2}$ production at the anode chamber 300 $\mathrm{ml}$ with all power supply.

EL-Salam canal water was used as substrate in MECs for production of volumes of bio-hydrogen at the anode chamber 300,400 and $500 \mathrm{ml}$ with power supply $0.4 \mathrm{~V}, 0.6 \mathrm{~V}$ and $0.8 \mathrm{~V}$ during fifteen days shown in Table (1). EL-Salam canal water is poor in organic matter contents compared to waste waters, therefore produced lowest volumes of bio-hydrogen production in MECs.

These results are consistent with those reported by Cucu et al., (2013) who also used the River Sabar water (in Romania) as substrate in MEC and MFC for bio-hydrogen production and electrical generation. Also , Afify, et al ., (2017 b ) reported that the hydrogen gas was significantly greater with power supply $0.4 \mathrm{~V}$.

Table 1. Volume of Bio- $\mathrm{H}_{2}\left(\mathrm{~cm}^{3}\right)$ produced at anode chamber 300, 400 and $500 \mathrm{ml}$ from El-Salam canal water with power supply $0.4 \mathrm{~V}, 0.6 \mathrm{~V}$ and $0.8 \mathrm{~V}$.

\begin{tabular}{|c|c|c|c|c|c|c|c|c|c|}
\hline \multirow[t]{2}{*}{ Days } & \multicolumn{3}{|c|}{$\begin{array}{c}\text { Volume of Bio- } \mathrm{H}_{2} \text { collected } \\
\left(\mathrm{cm}^{3}\right) \text { at anode chamber } 300 \mathrm{ml}\end{array}$} & \multicolumn{3}{|c|}{$\begin{array}{c}\text { Volume of Bio- } \mathrm{H}_{2} \text { collected } \\
\left(\mathrm{cm}^{3}\right) \text { at anode chamber } 400 \mathrm{ml}\end{array}$} & \multicolumn{3}{|c|}{$\begin{array}{c}\text { Volume of Bio- } \mathrm{H}_{2} \text { collected } \\
\left(\mathrm{cm}^{3}\right) \text { at anode chamber } 500 \mathrm{~m}\end{array}$} \\
\hline & $0.4 \mathrm{~V}$ & $0.6 \mathrm{~V}$ & $0.8 \mathrm{~V}$ & $0.4 \mathrm{~V}$ & $0.6 \mathrm{~V}$ & $0.8 \mathrm{~V}$ & $0.4 \mathrm{~V}$ & $0.6 \mathrm{~V}$ & $0.8 \mathrm{~V}$ \\
\hline 1 & 0.0 & 0.0 & 0.0 & 0.0 & 0.0 & 0.0 & 0.0 & 0.0 & 0.0 \\
\hline 2 & 0.0 & 0.0 & 0.0 & 0.0 & 0.0 & 0.0 & 0.0 & 0.0 & 0.0 \\
\hline 3 & 0.0 & 0.0 & 0.0 & 0.0 & 0.0 & 0.0 & 0.0 & 0.0 & 0.0 \\
\hline 4 & 0.0 & 0.0 & 0.0 & 0.0 & 0.0 & 0.0 & 0.0 & 0.0 & 0.0 \\
\hline 5 & 0.0 & 0.0 & 0.0 & 0.0 & 0.0 & 0.0 & 0.0 & 0.0 & 0.0 \\
\hline 6 & 0.0 & 0.0 & 0.0 & 0.0 & 0.0 & 0.0 & 0.0 & 5.06 & 6.07 \\
\hline 7 & 0.0 & 0.0 & 0.0 & 0.0 & 6.07 & 8.6 & 6.57 & 11.13 & 13.66 \\
\hline 8 & 0.0 & 0.0 & 0.0 & 5.06 & 12.14 & 16.19 & 12.65 & 17.2 & 19.73 \\
\hline 9 & 0.0 & 0.0 & 8.6 & 11.13 & 19.22 & 23.78 & 18.72 & 23.27 & 26.81 \\
\hline 10 & 7.08 & 8.09 & 13.15 & 17.2 & 26.31 & 29.85 & 24.79 & 29.34 & 33.9 \\
\hline 11 & 13.15 & 14.16 & 17.71 & 24.28 & 32.38 & 33.9 & 30.86 & 35.42 & 39.97 \\
\hline 12 & 16.69 & 17.2 & 20.74 & 33.39 & 34.91 & 37.95 & 36.93 & 41.49 & 46.04 \\
\hline 13 & 18.72 & 20.24 & 22.77 & 35.92 & 36.93 & 40.98 & 39.97 & 44.52 & 49.08 \\
\hline 14 & 19.73 & 21.75 & 23.78 & 36.93 & 38.96 & 43.01 & 41.49 & 46.04 & 50.6 \\
\hline 15 & 19.73 & 22.26 & 24.28 & 37.44 & 39.46 & 44.02 & 41.49 & 46.55 & 51.1 \\
\hline $\mathrm{V} \mathrm{H}_{2}$ & 19.73 & 22.26 & 24.28 & 37.44 & 39.46 & 44.02 & 41.49 & 46.55 & 51.1 \\
\hline \multicolumn{10}{|c|}{ LSD at $5 \%=3.48$} \\
\hline
\end{tabular}

Table 2 presents the hydrogen yield and volumes of Bio- $\mathrm{H}_{2}$ production from EL-Salam canal water. The lowest hydrogen yield $14.05 \%$ produced at the anode chamber $300 \mathrm{ml}$ with power supply $0.4 \mathrm{~V}$, which revealed significant differences were found between this yield and other yields at the anode chamber $400 \mathrm{ml}$ and $500 \mathrm{ml}$. No significant differences were found between all the hydrogen yield production at the anode chamber $300 \mathrm{ml}$ with all power supply. The highest hydrogen yield $31.18 \%$ and the highest volume of Bio$\mathrm{H}_{2} 51.1 \mathrm{~cm}^{3}$ production at the anode chamber $500 \mathrm{ml}$ with power supply $0.8 \mathrm{~V}$.

These results are consistent with those reported by Jia et al., (2010) who also obtained the highest hydrogen yield and highest volume of $\mathrm{Bio}-\mathrm{H}_{2}$ from wastewater with increasing power supply to $0.8 \mathrm{~V}$.

Hydrogen yield (\%) and Bio-hydrogen produced by Pseudomonas aeruginosa ATCC 27853 from ELSalam canal water:

MECs were filled with 30,40 and $50 \mathrm{ml}$ bacterial culture of Pseudomonas aeruginosa ATCC 27853 and
EL-Salam canal water (300, 400 and $500 \mathrm{ml}$ ) in anode chamber respectively.

Table 2. Hydrogen yield (\%) produced from ELSalam canal water in MECs.

\begin{tabular}{lcccccc}
\hline MECs & $\begin{array}{c}\text { Power } \\
\text { supply } \\
(\mathbf{V})\end{array}$ & $\begin{array}{c}\Delta \\
\mathbf{C O D} \\
(\mathbf{m g} /\end{array}$ & $\begin{array}{c}\mathbf{V H}_{\mathbf{2}} \\
\left(\mathbf{c m}^{3}\right)\end{array}$ & $\begin{array}{c}\mathbf{n}_{\mathbf{2}} \\
(\mathbf{m o l})\end{array}$ & $\begin{array}{c}{ }^{\mathbf{n}} \mathbf{t h} \\
(\mathbf{m o l})\end{array}$ & $\begin{array}{c}\mathbf{Y H}_{\mathbf{2}} \\
\mathbf{\%}\end{array}$ \\
\hline Anode & $0.4 \mathrm{~V}$ & 98 & 19.73 & 0.78 & 5.56 & 14.05 \\
chamber & $0.6 \mathrm{~V}$ & 99 & 22.26 & 0.88 & 6.18 & 14.27 \\
$300 \mathrm{ml}$ & $0.8 \mathrm{~V}$ & 99 & 24.28 & 0.96 & 6.18 & 15.56 \\
Anode & $0.4 \mathrm{~V}$ & 101 & 27.44 & 1.48 & 6.31 & 23.52 \\
chamber & $0.6 \mathrm{~V}$ & 101 & 39.46 & 1.56 & 6.31 & 24.79 \\
400 ml & $0.8 \mathrm{~V}$ & 102 & 44.02 & 1.74 & 6.37 & 27.38 \\
Anode & $0.4 \mathrm{~V}$ & 101 & 41.49 & 1.64 & 6.31 & 26.07 \\
chamber & $0.6 \mathrm{~V}$ & 102 & 46.55 & 1.84 & 6.37 & 28.97 \\
500 ml & $0.8 \mathrm{~V}$ & 104 & 51.1 & 2.02 & 6.5 & 31.18 \\
LSD at 5\% & \multicolumn{7}{c}{3.48} \\
\hline \multicolumn{7}{c}{ Table (3) presents the volumes of Bio- $\mathrm{H}_{2}\left(\mathrm{~cm}^{3}\right)$}
\end{tabular}

produced at anode chamber 300, 400 and $500 \mathrm{ml}$ by 
Pseudomonas aeruginosa ATCC 27853 from El-Salam canal water with $0.4 \mathrm{~V}, 0.6 \mathrm{~V}$ and $0.8 \mathrm{~V}$ of power supply. The highest volume of $\mathrm{Bio}-\mathrm{H}_{2} 148.25 \mathrm{~cm}^{3}$ starting produced at third day by Pseudomonas aeruginosa ATCC 27853 in MECs at $500 \mathrm{ml}$ of anode chamber with $0.4 \mathrm{~V}$ power supply obtained from ELSalam canal water, which revealed significant differences were found between other volumes. No significant differences were found between the lowest volumes of Bio- $\mathrm{H}_{2} 52.11 \mathrm{~cm}^{3}$ which starting produced from seventh day with $0.8 \mathrm{~V}$ at $300 \mathrm{ml}$ of anode chamber and other volumes production at $300 \mathrm{ml}$ of anode chamber. Significant negative relationship was observed between the volumes of Bio- $\mathrm{H}_{2}$ and all power supply at different anode chamber volumes (300, 400 and $500 \mathrm{ml}$ ) of EL-Salam canal water. Pseudomonas aeruginosa ATCC 27853 able to degradation of organic matter in EL-Salam canal water as substrate and electron transfer to electrodes in MEC for production of bio-hydrogen.

These results are agreed with the results obtained by Nivedhan et al.,(2014), who stated that Pseudomonas aeruginosa able to production the highest volume of bio-hydrogen during 15 days from glycerol as substrate using MEC with power supply $0.4 \mathrm{~V}$ to $0.8 \mathrm{~V}$.

Table 3. Volume of Bio- $\mathrm{H}_{2}\left(\mathrm{~cm}^{3}\right)$ produced at anode chamber 300, 400 and $500 \mathrm{ml}$ by Pseudomonas aeruginosa ATCC 27853 from El-Salam canal water with power supply $0.4 \mathrm{~V}, 0.6 \mathrm{~V}$ and $0.8 \mathrm{~V}$.

\begin{tabular}{|c|c|c|c|c|c|c|c|c|c|}
\hline \multirow[t]{2}{*}{ Days } & \multicolumn{3}{|c|}{$\begin{array}{c}\text { Volume of Bio- } \mathrm{H}_{2} \text { collected }\left(\mathrm{cm}^{3}\right) \\
\text { at anode chamber } 300 \mathrm{ml}\end{array}$} & \multicolumn{3}{|c|}{$\begin{array}{c}\text { Volume of Bio- } \mathrm{H}_{2} \text { collected } \\
\left(\mathrm{cm}^{3}\right) \text { at anode chamber } 400 \mathrm{ml}\end{array}$} & \multicolumn{3}{|c|}{$\begin{array}{c}\text { Volume of Bio- } \mathrm{H}_{2} \text { collected }\left(\mathrm{cm}^{3}\right) \text { at } \\
\text { anode chamber } 500 \mathrm{ml}\end{array}$} \\
\hline & 0.4 V & $0.6 \mathrm{~V}$ & $0.8 \mathrm{~V}$ & $0.4 \mathrm{~V}$ & $0.6 \mathrm{~V}$ & $0.8 \mathrm{~V}$ & $0.4 \mathrm{~V}$ & $0.6 \mathrm{~V}$ & $0.8 \mathrm{~V}$ \\
\hline 1 & 0.0 & 0.0 & 0.0 & 0.0 & 0.0 & 0.0 & 0.0 & 0.0 & 0.0 \\
\hline 2 & 0.0 & 0.0 & 0.0 & 0.0 & 0.0 & 0.0 & 0.0 & 0.0 & 0.0 \\
\hline 3 & 0.0 & 0.0 & 0.0 & 0.0 & 0.0 & 0.0 & 11.73 & 10.12 & 0.0 \\
\hline 4 & 0.0 & 0.0 & 0.0 & 0.0 & 0.0 & 0.0 & 29.85 & 23.78 & 9.1 \\
\hline 5 & 0.0 & 0.0 & 0.0 & 12.14 & 10.62 & 0.0 & 48.57 & 41.49 & 21.25 \\
\hline 6 & 9.1 & 8.6 & 0.0 & 24.28 & 16.69 & 10.12 & 63.25 & 55.15 & 38.45 \\
\hline 7 & 21.25 & 17.2 & 7.08 & 36.43 & 26.31 & 23.27 & 75.39 & 68.31 & 65.67 \\
\hline 8 & 31.87 & 24.79 & 15.18 & 50.09 & 35.42 & 34.4 & 89.56 & 81.4 & 69.82 \\
\hline 9 & 38.45 & 32.38 & 24.28 & 63.25 & 44.52 & 44.02 & 105.24 & 95.12 & 85 \\
\hline 10 & 45.03 & 39.97 & 31.37 & 74.38 & 54.64 & 53.63 & 114.86 & 109.29 & 98.67 \\
\hline 11 & 53.13 & 47.05 & 38.45 & 83.99 & 65.78 & 62.74 & 128.01 & 123.46 & 107.77 \\
\hline 12 & 60.21 & 55.15 & 45.03 & 93.1 & 75.39 & 70.84 & 141.17 & 131.56 & 115.87 \\
\hline 13 & 66.28 & 58.19 & 49.08 & 100.69 & 84.5 & 74.88 & 145.22 & 135.6 & 119.92 \\
\hline 14 & 69.32 & 60.21 & 51.1 & 107.27 & 88.55 & 76.91 & 147.24 & 137.63 & 122.45 \\
\hline 15 & 69.82 & 61.22 & 52.11 & 110.3 & 90.57 & 77.92 & 148.25 & 139.15 & 124.47 \\
\hline $\mathrm{V} \mathrm{H}_{2}$ & 69.82 & 61.22 & 52.11 & 110.3 & 90.57 & 77.92 & 148.25 & 139.15 & 124.47 \\
\hline
\end{tabular}

LSD at $5 \%=11.53$

The highest hydrogen yield $75.29 \%$ obtained by Pseudomonas aeruginosa ATCC 27853 in MECs at the anode chamber $500 \mathrm{ml}$ with power supply $0.4 \mathrm{~V}$ produced from EL-Salam canal water, which revealed significant differences were found between other yields. Table (4) presents the hydrogen yield and volumes of Bio- $\mathrm{H}_{2}$ production from EL-Salam canal by Pseudomonas aeruginosa ATCC 27853. No significant differences were found between the lowest hydrogen yield $30.91 \%$ and other yields production at the anode chamber $300 \mathrm{ml}$. Significant negative relationship was observed between the hydrogen yield and all power supply at different the anode chamber volumes (300, 400 and $500 \mathrm{ml}$ ) of EL-Salam canal water.

Also These results are in agreement with Cao et al., (2014) found that Pseudomonas aeruginosa able to degradation of organic matter in a variable substrates and electron transfer to electrodes in microbial electrolysis cell for bio-hydrogen production.

While the highest hydrogen yield $75.29 \%$ and the highest volume of Bio- $\mathrm{H}_{2} 148.25 \mathrm{~cm}^{3}$ production by Pseudomonas aeruginosa ATCC 27853 from EL-Salam canal water at the anode chamber $500 \mathrm{ml}$ with power supply $0.4 \mathrm{~V}$.
Table 4. Hydrogen yield (\%) production by Pseudomonas aeruginosa ATCC 27853 from EL-Salam canal water in MECs

\begin{tabular}{lcccccc}
\hline MECs & $\begin{array}{c}\text { Power } \\
\text { supply } \\
(\mathbf{V})\end{array}$ & $\begin{array}{c}\Delta \\
\mathbf{C O D} \\
(\mathbf{m g} /\end{array}$ & $\begin{array}{c}\mathbf{V H}_{\mathbf{2}} \\
\mathbf{( \mathbf { c m } ^ { 3 } )}\end{array}$ & $\begin{array}{c}{ }^{\mathbf{n}_{\mathbf{2}}} \mathbf{\mathbf { H } _ { \mathbf { 2 } }} \\
(\mathbf{m o l})\end{array}$ & $\begin{array}{c}\mathbf{n}^{\mathbf{t h}} \\
(\mathbf{m o l})\end{array}$ & $\begin{array}{c}\mathbf{Y H}_{\mathbf{2}} \\
\mathbf{\%}\end{array}$ \\
\hline Anode & $0.4 \mathrm{~V}$ & 110 & 69.82 & 2.77 & 6.87 & 40.29 \\
chamber & $0.6 \mathrm{~V}$ & 109 & 61.22 & 2.42 & 6.81 & 35.65 \\
300 ml & $0.8 \mathrm{~V}$ & 107 & 52.11 & 2.06 & 6.68 & 30.91 \\
Anode & $0.4 \mathrm{~V}$ & 117 & 110.3 & 4.37 & 7.31 & 59.84 \\
chamber & $0.6 \mathrm{~V}$ & 113 & 90.57 & 3.59 & 7.06 & 50.89 \\
400 ml & $0.8 \mathrm{~V}$ & 111 & 77.92 & 3.09 & 6.93 & 44.57 \\
Anode & $0.4 \mathrm{~V}$ & 125 & 148.25 & 5.88 & 7.81 & 75.29 \\
chamber & $0.6 \mathrm{~V}$ & 123 & 139.15 & 5.52 & 7.68 & 71.82 \\
500 ml & $0.8 \mathrm{~V}$ & 120 & 124.47 & 4.93 & 7.5 & 65.85 \\
LSD at 5\% & & & 11.53 & & & 4.93 \\
\hline
\end{tabular}

But the highest hydrogen yield $31.18 \%$ and the highest volume of Bio- $\mathrm{H}_{2}$ production $51.1 \mathrm{~cm}^{3}$ from Salam canal water at the anode chamber $500 \mathrm{ml}$ with power supply $0.8 \mathrm{~V}$ without addition of Pseudomonas aeruginosa ATCC 27853. Addition bacteria in MECs effect of increasing rate of hydrogen yield and volume of Bio- $\mathrm{H}_{2}$ (Table 5). The significant positive relationships were found between the hydrogen yield or volume of $\mathrm{Bio}-\mathrm{H}_{2}$ production and addition of bacteria. 
These results are agreed with the results obtained by Ujwal et al., (2015) who stated that $22.9 \%$ hydrogen gas was produced without bacteria from industrial wastewater and $45.8 \%$ hydrogen gas produced when Pseudomonas aeruginosa was added.

Table 5. Comparison of Hydrogen yield (\%) and volume of Bio- $\mathrm{H}_{2}\left(\mathrm{~cm}^{3}\right)$ produced with and without Pseudomonas aeruginosa ATCC 27853 from EL-Salam canal water:

\begin{tabular}{|c|c|c|c|c|c|}
\hline \multirow{2}{*}{ MECs } & \multirow{2}{*}{$\begin{array}{c}\text { Power } \\
\text { supply } \\
\text { (V) }\end{array}$} & \multicolumn{2}{|c|}{$\begin{array}{l}\text { Without } \\
\text { bacteria }\end{array}$} & \multicolumn{2}{|c|}{$\begin{array}{c}\text { Pseudomonas } \\
\text { aeruginosa } \\
\text { ATCC } 27853\end{array}$} \\
\hline & & $\begin{array}{c}\mathrm{VH}_{2} \\
\left(\mathrm{~cm}^{3}\right)\end{array}$ & $\begin{array}{c}\mathbf{Y H}_{2} \\
\%\end{array}$ & $\begin{array}{l}\mathrm{VH}_{2} \\
\left(\mathrm{~cm}^{3}\right)\end{array}$ & \\
\hline & & 1973 & 14.05 & 69.82 & \\
\hline chan & & 22 . & 14 & 61.22 & \\
\hline $300 n$ & 0.8 & 24 & & 52.1 & 0.91 \\
\hline & $0.4 \mathrm{~V}$ & 37.4 & 23 . & 110 & \\
\hline & & 39.4 & 24. & 90. & \\
\hline 4001 & $0.8 \mathrm{~V}$ & 44.02 & 27.38 & 77.92 & 44.57 \\
\hline & $0.4 \mathrm{~V}$ & 41.49 & 26.07 & 148.2 & 75.29 \\
\hline chamber & $0.6 \mathrm{~V}$ & 46.55 & 28.97 & 139.1 & 71.82 \\
\hline $500 \mathrm{ml}$ & $0.8 \mathrm{~V}$ & 51.1 & 31.18 & 124.47 & 65.85 \\
\hline LSD at $5 \%$ & & 3.48 & 1.9 & 11.53 & 4.93 \\
\hline
\end{tabular}

\section{REFERENCES}

Abd El-Rahman, N. K. (2017). Studies on Production of Bio-hydrogen from Bacteria. Ph. D.Thesis ,Fac. of Agric. Mans. Univ. pp.169.

Afify,Aida, H. ; M.M.Kassem;A.M.Abd El-Gwad and N.K.Abd El-Rahman (2017 a ). Biohydrogen Production by Escherichia coli NRRL B -3008 and Psudomonas aeruginosa ATCC 27853 Using Microbial Electrolysis Cells. J. Agric. Chem. And Biotechn., Mansoura Univ.Vol. 8 (2):63-68.

Afify,Aida, H. ;A.M.Abd El-Gwad and N.K.Abd ElRahman (2017 b ). Using Enterobacter aerogenes DSM 30053 for Bio-hydrogen Production by Microbial Electrolysis Cells from Domestic Wastewater. J. Agric. Chem. and Biotech., Mansoura Univ.,Vol. 8 (6):167-171.

Cao, C.; L. Chen and R. Wu (2014). Effecting of Dissolved Oxygen on Microbial Fuel Cells Based on Pseudomonas aeruginosa. J. Electro-Chem. Vol. (20): 382-386.
Cucu, A.; T. A. Costache; M. Divona; A. Tiliakos; I. Stamatin and A. Ciocanea (2013). Microbial Electrolysis Cell: Hydrogen Production Using Microbial Consortia from Romanian Waters. Digest. J. Nano-materials and Bio-structures. Vol. (8): 1179-1190.

Jia, Y. H.; J. Y. Choi ; J. H. Ryu ; C. H. Kim ; W. K. Lee ; H. T. Tran ; R. H. Zhang and D. H. Ahn (2010). Hydrogen Production from Wastewater Using a Microbial Electrolysis Cell. Korean J. Chem. Eng. Vol. 27 (6): 1854-1859.

Kotay, S. M. and D. Das ( 2008 ). Bio-hydrogen as a Renewable Energy Resource Prospects and Potentials. Int. J. Hydrogen Energy Vol. (33): 258-263.

Liu, H.; S. Grot and B. E. Logan (2005). Electrochemically Assisted Microbial Production of Hydrogen from Acetate. Environ. Sci. Technol. Vol. (39): 4317-4320.

Logan, B. E.; D. Call; S. Cheng; H. V. M. Hamelers; T. H. J. A. Sleutels and A. W. Jeremiasse (2008). Microbial Electrolysis Cells for High Yield Hydrogen Gas Production from Organic Matter. Environ. Sci. Technol. Vol. (42): 8630-8669.

Nivedhan K.; E. Anirudh ; S. Narayan ; L. A. Raj and H. P. Jagadish ( 2014 ). Hydrogen Production from Glycerol Using Microbial Electrolysis Cell. Int. J. of Res. in Eng. and Technol. Vol.3 (4) : 583-586.

Ujwal S. M.; M. A. Rakesh and L. A. Raj ( 2015 ). Biohydrogen production in microbial electrolysis cell using waste water from sugar industry. Int. J. of Engineering Sci. \& Res. Technol. Vol. 4 (4) : 452-458.

\section{تقييم بكتيريا Pseudomonas aeruginosa ATCC 27853 في إنتاج الهيلروجين الحيوى من مياه ترعة

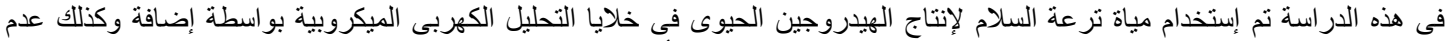

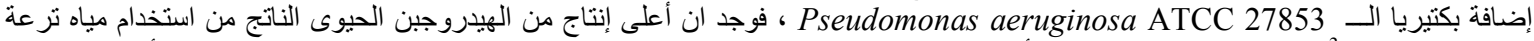

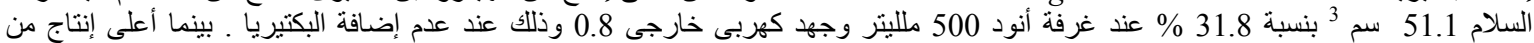

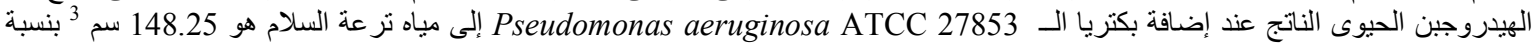

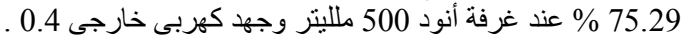

